高分子論文集 (Kobunshi Ronbunshu), Vol. 46, No. 3, pp. 183－188 (Mar., 1989)

\title{
クロトン酸二量体の酸無水物及びジメチルエステル とアクリロニトリルとの共重合
}

\author{
成智 聖司*1・阿久津 文彦*1・阿由葉 努*1 ・三浦 正敏*1
}

（受付 1988 年 9 月 27 日・審查終了 1988 年 12 月 12 日）

\begin{abstract}
要 旨 1-ヘキセン-3,4-ジカルボン酸無水物 (1a), (E)-2-ヘキセン-3,4-ジカルボン酸無水物 $(2 \mathrm{a}), 1$-ヘキセン-3,4-

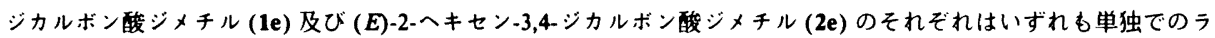
ジカル重合はしない.これらのモ/マーを $\mathrm{M}_{2}$ とし、アクリロニトリル $\left(\mathrm{AN}, \mathrm{M}_{1}\right)$ とのラジカル共重合を $60^{\circ} \mathrm{C} て ゙$ 行 い,モノマー反応性比を求めた。

$\begin{array}{lll}\text { AN-1a } & r_{1}=5.02, & r_{2}=0.00 \\ \text { AN-2a } & r_{1}=15.98, & r_{2}=0.00 \\ \text { AN-1e } & r_{1}=8.46, & r_{2}=0.00 \\ \text { AN-2e } & r_{1}=17.40, & r_{2}=0.00\end{array}$

同一モ/マー組成では，酸無水物とジメチルエステルいずれも末端オレフィン系 $(\mathbf{1 a}, 1 \mathrm{e})$ の方が対応する内部オレ フィン系 (2a, 2e) に比べて共重合体中での組成が高く，またこれらの共重合体の固有粘度はいずれもANの組成か 減少すると著しく低下することがわかった，AN-2a 及び AN-2e 共重合体の主鎖と側鎖に結合する二種のメチル基 を 'H NMR から判別した. AN-1a と AN-1eの共重合体の 'H NMR から二重結合の移動した 2a と 2e は含まれて いないことがわかった.
\end{abstract}

\section{1 緒言}

アリル系及び内部オレフィン系の化合物はいずれあ単 独重合しにくいが, 種々のビニル単量体とは共重合する ことか知られている，著者らは先に，クロトン酸の二量 体である1-ヘキセン-3,4-ジカルボン酸無水物 (1a), $(E)$ 2-ヘキセン-3,4-ジカルボン酸無水物 (2a) 及び 3-へキセ ン-3,4-ジカルボン酸無水物 (3a) のそれぞれとスチレン とのラジカル共重合を行い, $2 \mathrm{a}$ とスチレンとのモ/マー 反応性比を求めた。 しかし, 1a では共重合中 $60^{\circ} \mathrm{C}$ の加 熱で二重結合の移動を起こし， 1a の一部が $2 \mathrm{a} に$ に転移し てスチレンと共重合することが，共重合体の 'H NMR からわかった1.。また，3aでは立体障害のためほとんど 共重合性は認められなかった。

本報では 1a, 2a, 及び 3a の酸無水物, 及び 1-へキセン3,4-ジカルボン酸ジメル (1e), $(E)$-2-へキセン-3,4-ジカ ルボン酸ジメチル(2e)のそれぞれとアクリロニトリル (AN) との共重合について検討し，三，三の知見が得ら れたので報告する.

\footnotetext{
*1 干葉大学工学部合成化学科（ 260 千葉市弥生町 1-33）
}

\section{2 実験}

\section{1 モノマーの合成}

1-へキセン-3,4-ジカルボン酸 (1) は既報2),31の方法に よりクロトン酸ナトリウムの固相での熱反応によって令

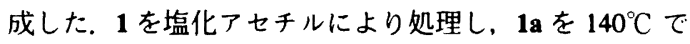
1 時間加熱し 2a を, また $1 \mathrm{a}$ 及び 2a を $210^{\circ} \mathrm{C}, 2.0$ 時閂の 加熱で 3a をそれぞれ前報")に従って合成した。

1eは1をジアゾメタンエーテル溶液でメチルエステ ル化して合成した2)，2e は2a $40 \mathrm{~g}$ を相当する $5 \%$ 水酸 化ナトリゥム水溶液で加水分解し, これをジアゾメタン でジメチルエステル化し，蒸留により精製した． bp $80.5^{\circ} \mathrm{C} / 3 \mathrm{mmHg}, 38 \mathrm{~g}(73 \%)$. ${ }^{1} \mathrm{H}$ NMR $\left(\mathrm{CCl}_{4}\right), \delta(\mathrm{ppm})$ $0.88(3 \mathrm{H}, \mathrm{t}), 1.65(2 \mathrm{H}, \mathrm{q}), 1.85(3 \mathrm{H}, \mathrm{d}), 3.35(1 \mathrm{H}, \mathrm{t}), 3.65$ $(6 \mathrm{H}, \mathrm{d}), 6.93(1 \mathrm{H}, \mathrm{q})$.

これらのモノマーの合成は Scheme 1 に示す.

\section{2 共重合}

AN と前述した種々のモノマーは所定のモル比に調製 し，各サンプルは5〜 6 gになるように秤量した. 2,2'-ア ゾビスイソブチロニトリル (AIBN) $4 \mathrm{mmol} / \mathrm{l}$ で開始 剂として用い,これをパイレックス製アンプルに入れ, 真空ラインで凍結融解法により脱ガスし, $60^{\circ} \mathrm{C}$ の一定温 度で所定時間加熱し, 塊状重合した. 反応物はメタノー 


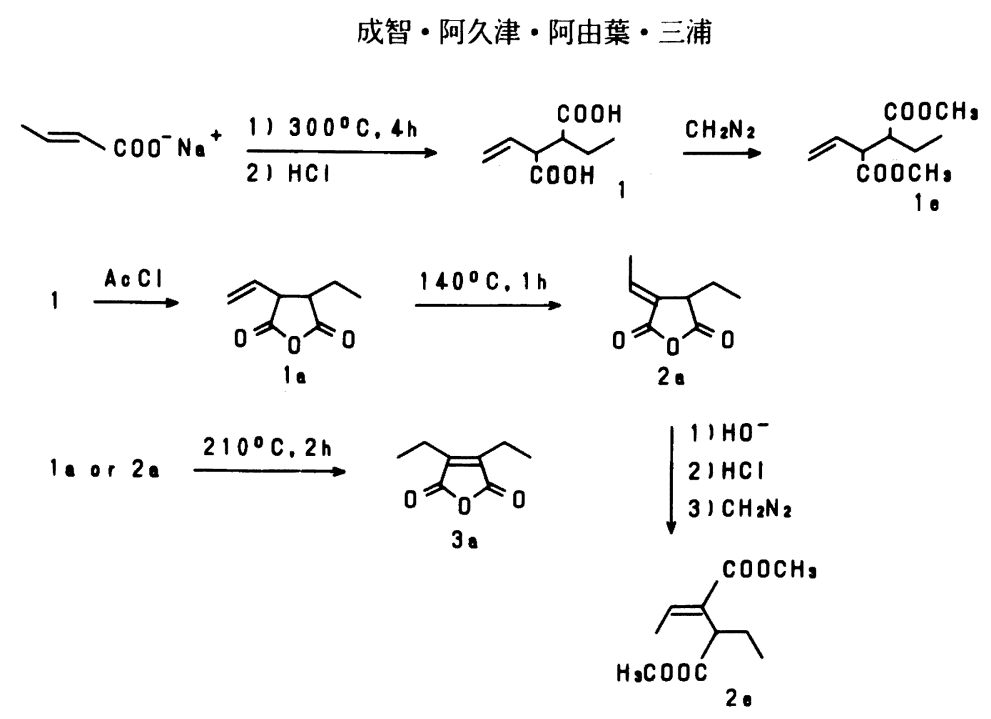

Scheme 1.

Table 1. Conditions and results of the radical copolymerization of 1-hexene-3,4-dicarboxylic anhydride (1a), (E)-2hexene-3,4-dicarboxylic anhydride (2a) and 3-hexene-3,4-dicarboxylic anhydride (3a) with acrylonitrile at $60^{\circ} \mathrm{C}$

\begin{tabular}{|c|c|c|c|c|c|c|}
\hline \multicolumn{2}{|c|}{ Comonomer } & \multirow{2}{*}{$\begin{array}{l}\text { Heating } \\
\text { time (h) }\end{array}$} & \multirow{2}{*}{$\begin{array}{c}\text { Conversion } \\
(\%)\end{array}$} & \multicolumn{2}{|c|}{ Copolymer } & \multirow{2}{*}{$\begin{array}{c}\eta_{\text {inh }} \\
(\mathrm{d} l / g)\end{array}$} \\
\hline $\mathbf{M}_{2}$ & $\operatorname{mol}(\%)$ & & & $\mathbf{N}(\%)$ & $\mathrm{mol} \%$ of $\mathbf{M}_{2}$ & \\
\hline 1a & 10.0 & 3.2 & 10.2 & 24.55 & 2.4 & 1.856 \\
\hline $1 \mathbf{a}$ & 20.0 & 6.3 & 7.3 & 23.30 & 4.4 & - \\
\hline 1a & 30.0 & 24.7 & 6.9 & 21.61 & 7.1 & 0.537 \\
\hline $1 \mathbf{a}$ & 39.9 & 62.5 & 3.2 & 19.39 & 11.2 & - \\
\hline 1a & 49.8 & 80.0 & 2.4 & 18.28 & 13.3 & 0.183 \\
\hline 1a & 64.9 & 115.0 & 0.8 & 14.66 & 21.6 & - \\
\hline $2 a$ & 10.0 & 48.0 & 11.6 & 25.30 & 1.5 & 0.834 \\
\hline $2 \mathbf{a}$ & 20.0 & 48.0 & 10.2 & 24.44 & 2.7 & 0.604 \\
\hline $2 \mathbf{a}$ & 30.0 & 152.5 & 6.1 & 23.33 & 4.3 & 0.243 \\
\hline $2 a$ & 40.0 & 152.5 & 3.3 & 22.94 & 4.9 & - \\
\hline $2 a$ & 50.0 & 168.3 & 4.4 & 21.76 & 6.9 & 0.114 \\
\hline $\mathbf{2 a}$ & 55.0 & 168.3 & 3.1 & 21.79 & 6.8 & - \\
\hline $\mathbf{2 a}$ & 60.0 & 168.3 & 1.7 & 21.75 & 6.9 & - \\
\hline $\mathbf{2 a}$ & 65.0 & 160.0 & 0.4 & 21.30 & 7.6 & - \\
\hline $3 \mathbf{a}$ & 20.0 & 3.5 & 17.6 & 25.77 & 0.8 & - \\
\hline $\mathbf{3 a}$ & 50.0 & 20.0 & 9.5 & 25.15 & 1.7 & 0.754 \\
\hline $3 \mathbf{a}$ & 70.0 & 40.0 & 9.6 & 24.99 & 1.9 & 0.412 \\
\hline
\end{tabular}

ル中に入れ，析出したポリマーをろ別乾燥した。分析試 料はさらにジメチルホルムアミド (DMF)ーメタノール で狂沈殿し精製した。酸無水物のポリマー試料はメタ ノールでの開環が考えられるが,この処理ではほとんど 影響しないことをIRから確認した。 さらに，空気中の 水分での加水分解に留意した。

\section{3 共重合体の分析及びスペクトルの測定}

共重合体の組成は窒素分析値から算出した. 固有粘度 の测走は DMF を溶媒として，ウベローデ粘度計を用い $30^{\circ} \mathrm{C}$ で測定した。
モノマーの 'H NMR スペクトルは日立 R-600, 60MHz NMR スペクトルメーター（ $\mathrm{CCl}_{4}$, 室温）で，また 共重合体は JEOL FX270 270-MHz NMR スペクトル メータ (DMSO- $\left.d_{6}, 100^{\circ} \mathrm{C}\right)$ で, それぞれ湘定した。

\section{3 結果亡考察}

\section{1 モノマー 2a 及び $2 \mathrm{e}$ の棈造}

$1 \mathrm{a}$ は熱的に不安定で容易に水素移動を起こし, 二重結 合位置が移動する。これを利用し，1a $140^{\circ} \mathrm{C}, 1$ 時間加 熱し単一成分とし 2a を得た。 $2 \mathbf{a}$ の幾何異性は次のよう 
Table 2. Conditions and results of the radical copolymerization of dimethyl 1-hexene-3,4-dicarboxylate (1e) and dimethyl $(E)$-2-hexene-3,4-dicarboxylate (2e) with acrylonitrile at $60^{\circ} \mathrm{C}$

\begin{tabular}{|c|c|c|c|c|c|c|}
\hline \multicolumn{2}{|c|}{ Comonomer } & \multirow{2}{*}{$\begin{array}{l}\text { Heating } \\
\text { time }(\mathrm{h})\end{array}$} & \multirow{2}{*}{$\begin{array}{c}\text { Conversion } \\
(\%)\end{array}$} & \multicolumn{2}{|c|}{ Copolymer } & \multirow{2}{*}{$\begin{array}{c}\eta_{\text {inh }} \\
\text { (d } l / g)\end{array}$} \\
\hline $\mathbf{M}_{2}$ & $\operatorname{mol}(\%)$ & & & $\mathrm{N}(\%)$ & $\mathrm{mol} \%$ of $\mathrm{M}_{2}$ & \\
\hline 1e & 10.1 & 1.2 & 6.8 & 25.00 & 1.2 & 1.769 \\
\hline 1e & 20.0 & 1.4 & 7.6 & 23.59 & 3.1 & - \\
\hline 1e & 30.0 & 3.0 & 6.9 & 21.22 & 4.4 & 1.549 \\
\hline 1e & 40.0 & 13.0 & 7.7 & 22.50 & 6.1 & 0.998 \\
\hline 1e & 49.5 & 20.3 & 12.5 & 19.23 & 9.0 & 0.790 \\
\hline le & 59.9 & 94.0 & 2.6 & 16.96 & 12.9 & - \\
\hline le & 69.8 & 99.4 & 1.6 & 13.74 & 19.8 & - \\
\hline $2 e$ & 10.0 & 2.8 & 4.3 & 25.51 & 0.9 & 1.463 \\
\hline $2 e$ & 20.0 & 5.3 & 4.4 & 24.73 & 1.8 & - \\
\hline $2 e$ & 30.0 & 28.0 & 4.4 & 23.77 & 2.9 & 0.695 \\
\hline $2 e$ & 40.0 & 31.0 & 4.5 & 22.93 & 3.9 & - \\
\hline $2 e$ & 50.0 & 48.0 & 2.8 & 21.73 & 5.4 & - \\
\hline $2 \mathbf{e}$ & 55.0 & 52.3 & 2.7 & 21.08 & 6.2 & 0.297 \\
\hline $2 e$ & 60.0 & 68.0 & 2.8 & 20.36 & 7.3 & - \\
\hline $2 \mathbf{e}$ & 65.0 & 92.0 & 2.9 & 19.52 & 8.5 & - \\
\hline $2 \mathbf{e}$ & 70.0 & 92.0 & 2.7 & 18.66 & 9.9 & - \\
\hline
\end{tabular}<smiles>CCC1C(=O)OC(=O)C1C(CC(CC(C)(C)C)CC(C)(C)C)C(C)(C)C</smiles><smiles>CCC1C(=O)OC(=O)C1(C(C)C)C(C)CC(C)(C)CN</smiles><smiles>CCC(C(=O)OC)C(CC(C#N)CC(C)(C)CNC#N)C(C(=O)OC)C(C)(C)C</smiles><smiles>CCC(C(=O)OC)C(C(C)C)(C(C)C)C(C)C(C#N)C(C)(C)C</smiles>

Scheme 2.
にして調べた.

$1 \mathrm{e}$ を $240^{\circ} \mathrm{C}, 20$ 時間の加熱では2-へキセン-3,4- ジカル ボン酸ジメチルを与えるが, このとき $E, Z$ 体の 2 種の 異性体が，ほぼ等量の割合で生成し，それぞれ 'H NMR スペクトルから，Z体ではカルボニル基の影響により二 重結合に結合したメチル基プロトンは $2.08 \mathrm{ppm} に 、 メ$ チンプロトンが $6.10 \mathrm{ppm}$ にシフトするのに対し， $E$ 体 ではそれぞれ $1.85,6.93 \mathrm{ppm}$ にシフトすることを既報 ${ }^{2}$ で報告した。

2a の水酸化ナトリウムによる加水分解生成物のジメ チルエステルの 'H NMR スペクトルは, 前述した $E$ 体 のスペクトル值に一致した。したがって, $2 \mathrm{e}$ は $E$ 体の構 造を有し, 加水分解前の酸無水物 2a は $E$ 体で Scheme 1 に示す構造であることを確認した。

\section{2 共重合}

AIBNを開始剤とし，仕込みモノマーの割合を種々变 化させて共重合を行い, 生成した共重合体の組成及び活 有粘度を Table 1 及び Table 2 に示した。

これらの酸無水物及びジメチルェステルの反応性はい ずれの場合む乏しく，モノマーの割合が AN に対し，増 加すると重合率は著しく低下した，また，共重合体中の これらのモノマー $\mathbf{M}_{2}$ の含有量は什込みモノマー中の含 有量に比べ著しく少ない.

Table 1，2 に示す共重合体の固有粘度は酸無水物， $シ$ メチルエステルの末端オレフィン系及び共役系では，い ずれもコモノマー $\mathbf{M}_{2}$ の含有率兽加するとともに低下 した，末端オレフィン系と共役系を比較すると、问程度 

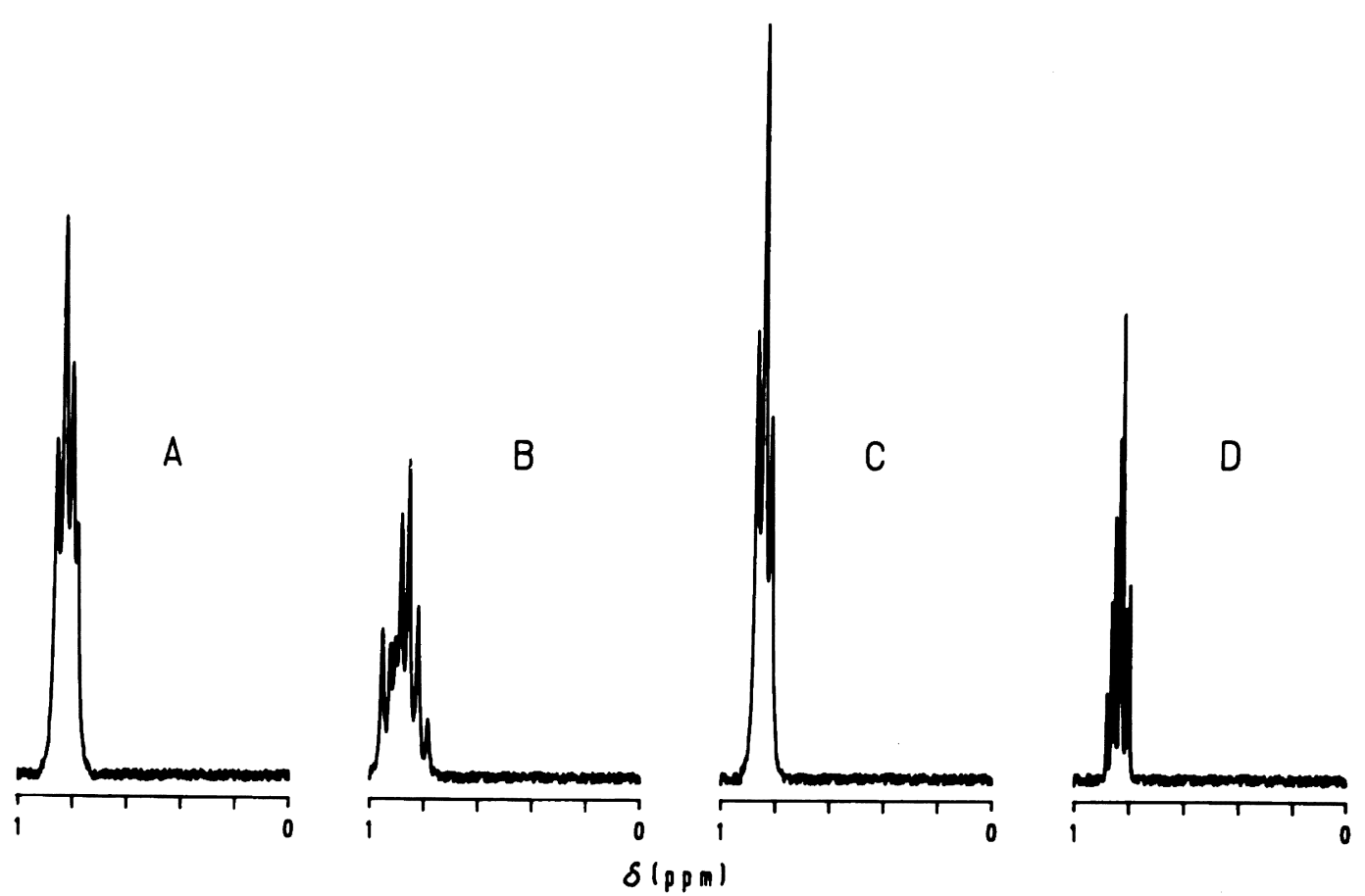

Fig. 1. 'H NMR spectra (270 MHz, DMSO- $d_{6}$ at $\left.100^{\circ} \mathrm{C}\right)$ : A, AN-1a copolymer (13.3\%); B, AN-2a copolymer (6.8\%); C, AN-1e copolymer (12.9\%); D, AN-2e copolymer (8.5\%). Values in parentheses show contents of $\mathbf{M}_{2}$ monomer in mol\%.

の $\mathbf{M}_{2}$ の含有率に対し，共役系の方がはるかに低い固有 粘度をふした。例えば, $1 \mathrm{a}$ の共重合体の $\mathrm{M}_{2}$ が $7.1 \mathrm{~mol} \%$ で $0.537 \mathrm{~d} l / \mathrm{g}$ の固有粘度を与えるのに対し，2a の共重合 体では $6.9 \mathrm{~mol} \%$ で $0.114 \mathrm{~d} / / \mathrm{g}$, またジメチルエステル $1 \mathrm{e}$ 及び $2 \mathrm{e}$ の共重合体ではそれぞれ，6.1 mol\% で $0.998 \mathrm{~d} / /$ g, $6.2 \mathrm{~mol} \%$ で $0.297 \mathrm{~d} / \mathrm{g}$ を与えた.これらの結果はいず れも重合性の之しい $\mathbf{M}_{2}$ での共重合体の方が低い固有粘 度を小した。このことは末端 $\mathbf{M}_{2}$ の反応性が悪く連銷生 長を阻害し，この効果は末端オレフィン系より共役系の 施がよりきいためと考えられる。

1a, 2a, 1e, 及び 2e のそれぞれと AN との共重合体では Scheme 2 にホすような構造が予想される. AN-2a (copolymer B), AN-2e (copolymer D) での共重合体では主 銷に結合したメチル基と側銷のメチル基が存在するのに 刘し, AN-1a (copolymer A) 及び AN-1e (copolymer C) では上銷のメチル基は存在しない，そこで，これら2種 のメチル基の存在を検討するため, 4 種の共重合体の ' $\mathrm{H}$ NMR スペクトル (DMSO- $\left.d_{6}, 100^{\circ} \mathrm{C}\right)$ を測定した結果を Fig. 1 に示す.

Copolymer A， C では主鎖に結合したメチル基はなく， 側鎖のメチル基が，それぞれ $0.83 ， 0.84 \mathrm{ppm}$ に三重線と して認められるのに対し， copolymer B,Dでは主鎖，側
鎖に結合した 2 種のメチル基が多重線として，それぞれ $0.86,0.84 \mathrm{ppm}$ に認められ，これらの結果は予想した構 造を支持している.

Copolymer Cでは 1e の二重結合が $2 \mathrm{e}$ に転移すること なく AN と共重合しているのに対し, copolymer A では 三重線に小さなピークか認められることから，其重合体 中に微量の 2a が含まれていることが考えられる.

\section{3 モノマー $\left(\mathbf{M}_{2}\right)$ の重合性}

AN-1a, AN-2a, AN-1e, 及びAN-2eについての共重合 組成曲線をそれぞれ Fig. 2, 3, 4 及び5に示した。 モ， マー反応性比は曲線合致法4)を用いて算出した。

$$
\begin{array}{llll}
\text { AN-1a } & r_{1}=5.02, & r_{2}=0.00, & 1 / r_{1}=0.199 \\
\text { AN-2a } & r_{1}=15.98, & r_{2}=0.00, & 1 / r_{1}=0.063 \\
\text { AN-1e } & r_{1}=8.46, & r_{2}=0.00, & 1 / r_{1}=0.118 \\
\text { AN-2e } & r_{1}=17.40, & r_{2}=0.00, & 1 / r_{1}=0.057
\end{array}
$$

1a は $60^{\circ} \mathrm{C}, 20$ 時間の加熱でその $20 \%$ が転移して 2a になることを前報”で報告した，したがって，AN-1aの 共重合では 1aの一部が 2aに転移しており，上記の AN1a の反応性比は転移した 2aについての補正を行ってい ないので正確な值とはいえない，生成共重合体の ${ }^{1} \mathrm{H}$ NMR から，共重合に組み込まれている $\mathrm{M}_{2}$ はほとんど 1a の形で，ごく微量の 2a を含むことがわかった。 した 


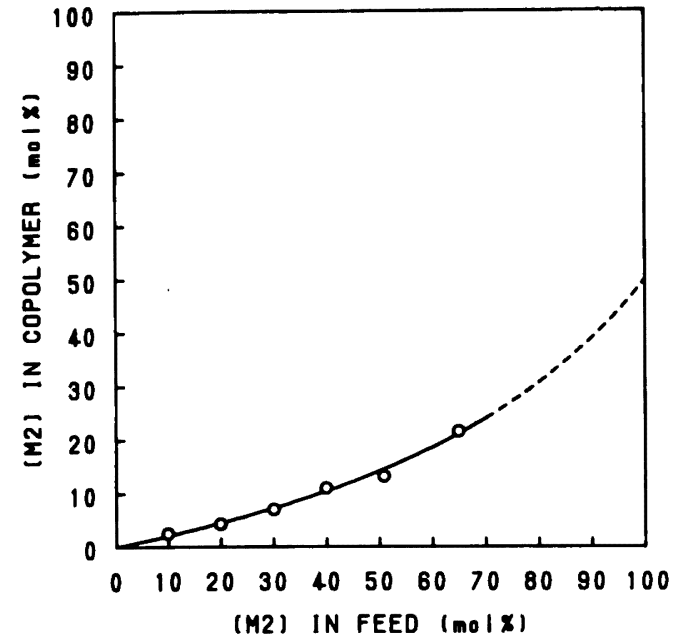

Fig. 2. Mole fraction of monomeric units of $M_{2}$ in the copolymer as a function of the mole fraction of monomer $\mathbf{M}_{2}$ in the feed for the copolymerization of acrylonitrile $\left(\mathrm{M}_{1}\right)$ with 1-hexene-3,4-dicarboxylic anhydride $\left(\mathrm{M}_{2}\right)$.

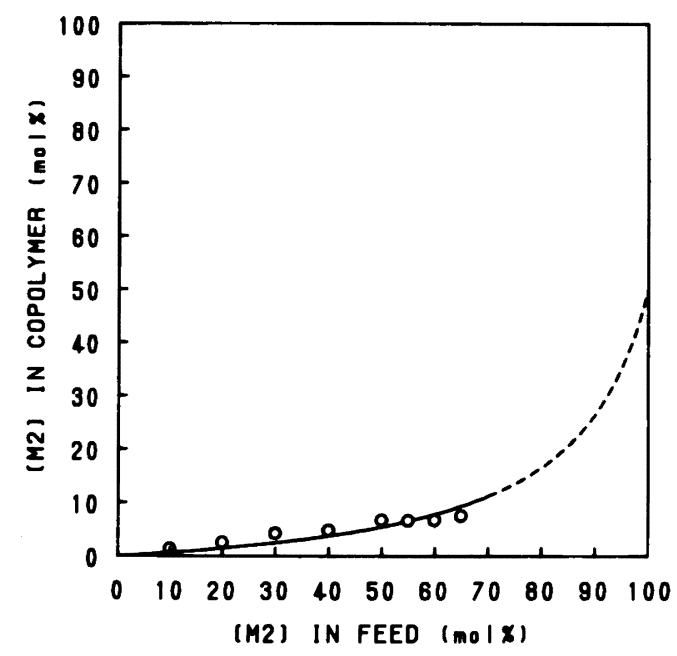

Fig. 3. Mole fraction of monomeric units of $M_{2}$ in the copolymer as a function of the mole fraction of monomer $\mathbf{M}_{2}$ in the feed for the copolymerization of acrylonitrile $\left(M_{1}\right)$ with $(E)$-2-hexene-3,4-dicarboxylic anhydride $\left(\mathrm{M}_{2}\right)$.

がって、一部 2a への転移が起こっても共重合は主とし て 1a と起こると考えられる，2a との共重合を無視する ならば，転移を考虑すると， $r_{1}$ は上記の値より小さくな り，1/r,はより大きくなるはずである，1eは共重合の反 伈条件では転移は全く認められなかった。

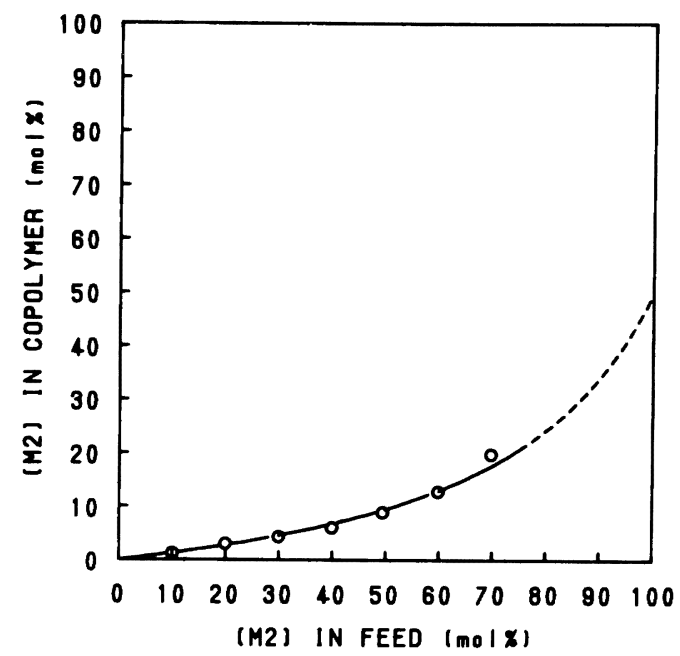

Fig. 4. Mole fraction of monomeric units of $\mathbf{M}_{2}$ in the copolymer as a function of the mole fraction of monomer $\mathbf{M}_{2}$ in the feed for the copolymerization of acrylonitrile $\left(M_{1}\right)$ with dimethyl 1-hexene-3,4-dicarboxylate $\left(\mathrm{M}_{2}\right)$.

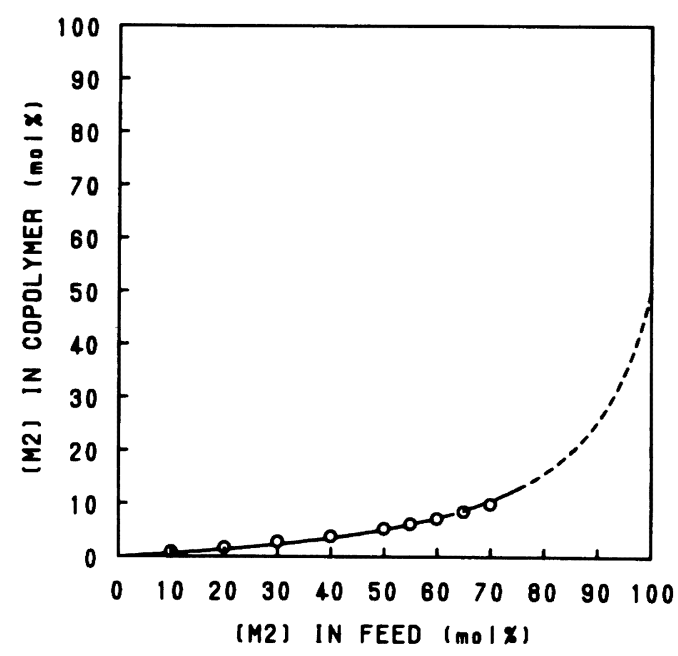

Fig. 5. Mole fraction of monomeric units of $M_{2}$ in the copolymer as a function of the mole fraction of monomer $\mathbf{M}_{2}$ in the feed for the copolymerization of acrylonitrile $\left(\mathrm{M}_{1}\right)$ with dimethyl $(E)$-2-hexene-3,4-dicarboxylate $\left(\mathrm{M}_{2}\right)$.

末端オレフィン系である 1a, 1e は内部オレフィン系の 2a，2e に比べ AN に対する共重合性がかなり良いことが わかった，前者は非共役モノマーで，後者は共役モノ マーであり，AN は共役モ/マーであるから，この郌で は後者の方が共重合性が良いはずである。しかし, 後者 
のモノマーは内部オレフィンのためメチル基障害があ り、またカルボニル基が共役の位置にあるため二重結合 の㫣子密度加低く，さらに AN $の-C N$ 基も強い電子吸 引基であるから，これらの効果はANに対する後者の共 重命性を低卜させるであろう。前者は非共役モ/マーで あるが、メチレン基がビニル基とカルボ二ル基の間に存 化するため, カルボニル基の電子吸引性がかなり弱めら れる.このことは，AN との極性の差を大きくし，共重 合性を增大させる，前報でスチレン-2a の共重合につい て垠筂したか，この系の $1 / r_{1}$ （ $M_{1}$, スチレン）は 0.224 で、AN-2aのそれに比較しかなり大きい，また，スチレ ン-1a の其重合では，1a が反応中に転移した 2a が共重 令体に組み込まれていた。これはスチレンが無極性モノ

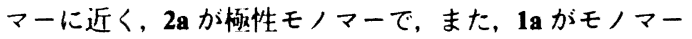
としては極性が低いためである。極性モノマーのANで は、スチレンとの共重合とは逆の関係になり，2aより 1a と共重合しやすく，1a の共重合で 1aの一部が 2aに転移 しても主として1a が反応する。また，酸無水物である 1a, 2a とジェステルの 1e, 2e とを比較すると, 前者の力 が共重合性がいくぶん高い。これは2 個のメトキシカル ボニル基の方が, 分子内酸無水物として環を形成してい る場合よりも，付加への立体障害が大きいためと考えら れる.

\section{文献}

1) K. Naruchi, F. Akutsu, and M. Miura, Makromol. Chem., Rapid Commun., 8, 281 (1987).

2) 成智聖司, 田中誠次, 山本 忠, 山田和俊, 日本化学会誌, 1291 (1983).

3) K. Naruchi and M. Miura, J. Chem. Soc., Perkin Trans., 2, 113 (1987).

4) B. Yamada, M. Itahashi, and T. Otsu, J. Polym. Sci., Polym. Chem. Ed., 16, 1719 (1978).

\section{Copolymerization of Anhydrides and Dimethyl Esters of Crotonic Acid Dimer with Acrylonitrile}

Kiyoshi Naruchi*1, Fumihiko Akutsu*1, Tsutomu Ayuha*1, and Masatoshi MiURA*1

${ }^{* 1}$ Department of Synthetic Chemistry. Faculty of Engineering, Chiba University (Yayoi-cho, Chiba-shi, 260 Japan)

1-Hexene-3,4-dicarboxylic anhydride (1a), (E)-2-hexene-3,4-dicarboxylic anhydride (2a), dimethyl 1-hexene-3,4dicarboxylate (1e) and dimethyl (E)-2-hexene-3,4-dicarboxylate (2e) do not radically homopolymerize. Radical copolymerization of these monomers $\left(\mathrm{M}_{2}\right)$ with acrylonitrile $\left(\mathrm{AN}, \mathrm{M}_{1}\right)$ was conducted at $60^{\circ} \mathrm{C}$ with $\mathrm{AIBN}$, and the following monomer reactivity ratios were obtained:

$$
\begin{array}{lll}
\text { AN-1a } & r_{1}=5.02, & r_{2}=0.00 \\
\text { AN-2a } & r_{1}=15.98, & r_{2}=0.00 \\
\text { AN-1e } & r_{1}=8.46, & r_{2}=0.00 \\
\text { AN-2e } & r_{1}=17.40, & r_{2}=0.00
\end{array}
$$

At the same $\mathbf{M}_{1} / \mathbf{M}_{2}$ feed ratio, the terminal-olefinic monomers (1a and 1e), whether acid anhydride or ester, led to higher contents in the copolymers than the inner-olefinic counterparts (2a and $2 \mathrm{e}$, respectively). The viscometric molecular weights of the copolymers decreased significantly with a decrease in acrylonitrile content in the monomer feed. For the AN-2a and AN-2e copolymers, the two types of methyl groups, one attached to the main chain and the other to the side chain, were discriminated by 'H NMR spectroscopy. 'H NMR analysis of the AN-1a and AN-1e copolymers thus showed that they did not contain repeat units derived from $2 a$ and $2 e$ which would be formed by migration of the double bond of $1 \mathrm{a}$ and $1 \mathrm{e}$, respectively.

KEY WORDS Crotonic Acid Dimer / Copolymerization / Monomer Reactivity Ratio / Acrylonitrile / (Received September 27, 1988: Accepted December 12, 1988)

[Kobunshi Ronbunshu, 46(3), 183-188 (1989)] 